\title{
A brief introduction to a hertzian reading of Wittgenstein"s Tractatus
}

Uma breve introdução à leitura hertziana do tratado de Wittgenstein

\begin{abstract}
The purpose of this short text is to present the hypothesis that there are remarkable influences of the thinking of the physicist Heinrich Hertz - especially his Principles of Mechanics (1894) - on Wittgenstein's Tractatus Logico-Philosophicus (1922). Indeed, it is widely recognized that some sort of influence of Hertz on Wittgenstein must exist; however, how and to what extent the relationship between the two thinkers was important is not unanimously resolved. We propose here three broad areas in which the thought of Wittgenstein in the Tractatus can be tributary of the mechanical system developed by Hertz (with all its additions and improvements): ontology, theory of figuration and philosophy of science. In this respect, it should be mentioned that Wittgenstein was always parsimonious in admitting to influences; though he referred to Hertz several times in his writings, he nowhere clarified the extent of Hertz's influence on his thinking. Moreover, we consider the specialized literature on this topic neither clear nor convincing. Therefore, we aim at our own interpretation and routing of some points of what still seems to be wrapped cloaked mystery: the influence of Hertz on Wittgenstein's Tractatus.
\end{abstract}

Keywords: Hertz. Wittgenstein. Ontology. Theory of figuration. Philosophy of science.

\section{RESUMO}

O objetivo desse pequeno texto é apresentar hipótese de que existem influências notáveis do pensamento do físico Heinrich Hertz - especialmente em Os Princípios da Mecânica (1894) - sobre o Tractatus Logico-Philosophicus (1922), de Wittgenstein. De fato, é amplamente reconhecido que algum tipo de influência de Hertz sobre Wittgenstein deve existir; no entanto, como e em que medida a relação entre os dois pensadores foi importante não está unanimemente resolvida. Propomos aqui três amplas áreas em que o pensamento de Wittgenstein no Tractatus pode ser tributário do sistema mecânico desenvolvido por Hertz (com todas as suas adições e melhorias):

* Doutor em Filosofia pela (UFSCar). https://orcid.org/0000-0001-7375-8574 
a ontologia, a teoria da figuração e a filosofia da ciência. A esse respeito, deve-se mencionar que Wittgenstein sempre foi parcimonioso ao admitir influências; apesar de se referir a Hertz várias vezes em seus escritos, em nenhum lugar ele esclareceu a extensão da influência de Hertz sobre o seu pensamento. Além disso, consideramos a literatura especializada sobre este tema não é clara e nem convincente. Portanto, visamos nossa própria interpretação e encaminhamento de alguns pontos do que ainda parece ser um mistério: a influência de Hertz sobre o Tractatus de Wittgenstein.

Palavras-chave: Hertz. Wittgenstein. Ontologia. Teoria da figuração. Filosofia da ciência.

There has been much speculation about the Tractatus' themes, and about their possible sources of inspiration. What were the sources of Wittgenstein's discussions on ontology, figuration, philosophy, logic, mathematics, science and mysticism that appear in that work? Diverse answers have been offered to such questions. Safe suggestions include the names of Boltzmann, Hertz, Schopenhauer, Frege, Russell, Spengler, Sraffa - these, according to Wittgenstein himself, had direct influence on his work (MCGUINNESS, 1988). Of these, Frege and Russell are always mentioned as having had a philosophical impact on the young Wittgenstein. However, most interpreters of Wittgenstein's thought seem to ignore one of the philosopher's own statements about the nature of his work: "it projected itself from the foundations of logic to the nature of the world" (NB, 2.8.16). In this sense, one cannot ignore the fact that, though at first the work of Frege and Russell provided a scientific theory of language - thus exempting it from any misunderstanding that might be produced by its superficial form (until the Notebooks 1914-1916, for example, Wittgenstein showed much more concern with pursuing the ideal of complete logical analysis and had not yet presented a world view) -, the work of Hertz then inspired his idea about which features the world had to have in order to be represented. This agrees with the Tractarian movement from logic to ontology, following the paths of science as something that contains elements of an a priori representation of the world, and culminating with the view that the mystical (as well as the ethical and aesthetic) is ineffable.

No one knows the real contribution of contextual understanding of the biography of a thinker to an understanding of the development of his own thought. There are things which can only be revealed by textual readings, focusing on rebuilding the internal coherence of words in trying to interpret his thought. In the case of Wittgenstein, however, it is necessary to pay attention to his intellectual biography: his transition from mathematics to philosophy, by means of engineering, would leave more marks on the Tractatus than has hitherto been recognized. His training as an engineer in Berlin and Manchester, from 1906 until his arrival at Cambridge in 1911 to study with Russell, was not just a pastime in terms of his intellectual development. "To be sure, he became interested in Logic and Mathematics through a personal interest in the philosophical foundations of natural science - in philosophy of science. The works of scientists he read during his teens - Die Prinzipen der Mechanick [The Principles of Mechanics] of Heirinch 
Hertz, and Populäre Schriften [Popular Writings], by Ludwig Boltzmann - do not suggest an interest in engineering mechanics, not even in theoretical physics, but in the philosophy of science" (MONK, 1995, p. 38). But as we do not know, in fact, the importance of Boltzmann for the formation of young mind and the philosophy Wittgenstein - which still must be explored - we will restrict our reflections to Hertz's philosophy of science and its real influence on the Tractatus of Wittgenstein. Our reflection will proceed from three fronts. First, we will try to understand the ontology of the Tractatus (TLP, 1 - 2063) from the viewpoint of the foundations of the mechanics of Hertz; secondly, we will investigate the similarity of the Tractatus' theory of figuration (TLP, 2.1 - 3.5) with the mode of representation proposed in The Principles of Mechanics; and thirdly, we will interpret the science of the Tractatus (TLP, 6.3 - 6372) from a Hertzian perspective, as something that contains a priori elements - the framework of our description of the world.

With regards to the idea that the ontology of Wittgenstein's Tractatus is dependent on the mechanical system of Hertz, this is a hypothesis that may be verified by means of associating elements of the former (simple object, logical space, concatenation...) with the elements of the hertzian mechanics (material particles coordinates, systems of material points, structure). According to this hypothesis, what Wittgenstein does is to reapply the concepts that were worked out in The Principles of Mechanics; its confirmation will be guided mainly by an understanding of the concepts of simple objects in Wittgenstein and material particles in Hertz. At first sight, there is no reason to doubt that this would be a plausible analysis; all that is required is an understanding of the function of such objects in the Tractarian system and material particles in Hertz: Both systems appear to deal with coordinated logical entities rather than physical entities: they can be understood in the manner of Kantian forms of space and time - therefore as a priori conditions of experience. Rather than the material particles with which physics is concerned, they are logical elements.

With respect to the theory of figuration presented in the Tractatus, and bearing in mind that Wittgenstein was an attentive reader of Hertz's work (it is quoted often), the theory of representation of hertzian mechanics is a likely source of inspiration. Hertz uses the term Darstellung when he qualifies a representation as scientific - for example, graph representations as currently used in physics. But he mainly uses the word Bild, which in German literally means "picture" or "image", such as representations, models, cognitive schemata - "images produced by our mind and necessarily affected by the characteristics of its mode of representation (portrayal)" (HERTZ , 1956, p. 2). In the aphorisms of the Tractatus that deal with the theory of figuration, the word "Bild" is used in the same way. Representation and figuration are therefore terms which point to the same object - namely, "that we figure facts" (TLP, 2.1). And here, again, the similarity is manifest. Wittgenstein begins his theory of figuration with the following assertion: "we figure the facts" (TLP, 2.1); Hertz, on the first page of the introduction to his The Principles of Mechanics writes, "we produce the forms and symbols of external objects for ourselves", and "the form we attribute to them is such that the necessary consequences of the images in thought are always the images of the necessary consequences in nature of things depicted" (HERTZ, 1956, p. 1). Apparently, according to what Hertz wrote, there must be some agreement between nature 
and our thinking. Wittgenstein said something very similar: there must be something in common between fact and figure (TLP, 2.16, 2.161), there must be agreement because the names we use should behave like objects behave in nature. And what will representations share with facts? Among other things, Wittgenstein says that a figure should have the same numerical multiplicity as its fact (TLP, 4:04 b). Likewise Hertz states that a system which is the model of another must satisfy the condition "that the number of coordinates of the first system be equal to the number of the second" (HERTZ, 1956, p. 175). And that "if a system is the model of a second, then, conversely, the second is a model of the first; and if two systems are models of a third system, then each of these systems is also a model of the others" (HERTZ , 1956, p. 175). As the thoughts in our mind are representations, they are covered by this internal relation: "the relationship between a dynamic model and the system of which it is a model is precisely the same relationship as that which can be established between the images of things produced by our mind and things themselves" (HERTZ, 1956, p. 177). In this system, the simplest things we deal with in representations or models are, according to Hertz, "material particles" and "material points". In the case of Wittgenstein, they are "objects". The objects are eternal (TLP, 2.027); they cannot be destroyed. Hertz's material points are also "invariable and indestructible" (HERTZ, 1956, p. 46). A system is an aggregate of material points; the world is, at least in part, an aggregate of material points. The models - or our representations of the world - are constructed in a similar way, from the symbols that represent these material points.

Like Hertz, who sought for the science of mechanics foundations which do not posit anything about things in themselves ${ }^{1}$ and do not appeal to pseudo concepts such as "strength" and "energy", Wittgenstein sought the conditions of meaningful propositions (of saying something significant about the world) by disqualifying from (scientific) discourses any term without meaning or which points to pseudo problems. The sole valid elements of Hertz's physics - the systems of material points - reappear in Wittgenstein as absolutely simple, indestructible and eternal objects. We can postulate the behavior of certain systems, or the laws which govern them, and check whether they occur in nature; but the nature of the object, or the simple, can only be logically defined.

Hertz's objective of establishing the limits of physics from within physics itself may have inspired the Tractatus; it may have encouraged Wittgenstein regard the relation between thought and the world as logical and not empirical. With respect to empirical propositions, these encounter, as the condition of internal and formal possibilities, an ontological discourse about reality, since "the empirical reality is limited by the totality of objects" (TLP, 5.5561). The role of logic in this context is to present the parallelism of the a priori orders of the world and thought: in the case of thought, the order of meaningful propositions (the propositions of science); as regards the world, the order states of affairs. Both systems, in this

\footnotetext{
"The subject-matter of the first book is completely independent of experience. All the assertions made are a priori judgments in Kant's sense. They are based upon the laws of the internal intuition of, and upon the logical forms followed by, the person who makes the assertions; with his external experience they have no other connection than these intuitions and forms may have." (HERTZ, 1956, p. 45).
} 
case, seem not to assume anything about the external connections of his theories, but rather, they serve to ensure formal consistency, and become the ultimate expression of general and formal independence.

Finally, the philosophy of science perspective of the Tractatus can also be understood from a hertzian perspective. It is entirely plausible to interpret the aphorisms of the Tractatus dealing with science (TLP, 6.3-6372) from the perspective of the mechanics of Hertz - descriptions of the world contain a priori elements. This is clearly the case with respect to Hertz's "material particle": a combination of points in a kind of coordinate system. In The Principles of Mechanics he is not dealing with the material particles of particle physics, but with logical simplicity. He describes a Massenteilchen (material particle) as a characteristic property of space and time, and not as a material object in space and time. Material particles are properties of space and do not have spatial extension (they do not, for example, have the property of being heavy); their function is simply to mark a single location in space-time. As an elaboration of the understanding of material the concept of mass $^{2}$ can be understood within the Kantian forms of space and time, and, therefore, as an a priori experience. Interpreted as an a priori definition of mass, we can say that one can choose a certain area of points in space, defined by a set of coordinates, and use that as a unit of measure so as to define the mass of some other set of points in space. And what was the approximation of the above ways of conceiving the workings of science? Hertz's model seems very much like the Tractarian "method" for defining a configuration, describing it completely through a network of meshes of a given width (TLP, 6342). "The network, however, is purely geometrical; all its properties can be given a priori" (TLP, 6.35). Wittgenstein's image of irregular black spots on a white surface as the Hertzian system of coordinates, provides a simple projection of the distribution of material points in space, i.e., it indicates that there are points in space in combination with forms of patches. And the network itself is a coordinated system in which the distribution of patches is defined. Such a network could be more or less thin and thus it could more or less describe facts accurately. This metaphor clarifies the qualities and widths of networks of all types that represent different modes (or different systems) of describing the world. Once again Hertzian mechanics Wittgenstein's model:

Mechanics determines one form of description of the world by saying that all propositions used in the description of the world must be obtained in a given way from a given set of propositions-the axioms of mechanics. It thus supplies the bricks for building the edifice of science, and it says, 'Any building that you want to erect, whatever it may be, must somehow be constructed with these bricks, and with these alone.' (TLP, 6.341).

Therefore, both Wittgenstein's view science and his conception of the world, and the definition that we figure facts are fully in line with the philosophy of science of Hertz.

The relevance of a Hertzian reading of the Tractatus rests, therefore, first, on one of the reasons already given above: if the influence of Hertz's thought on

\footnotetext{
2 "The number of material particles in any space, compared with the number of material particles in some chosen space at a fixed time, is called the mass contained in the first space." (HERTZ, 1956, p. 46).
} 
Wittgenstein is recognized, it is inversely proportional to the reasons offered to justify this importance. Secondly, the gap is visible when the subject is approached from the point of view of the academic literature, because what we have found regarding this influence are superficial analyses without concern for depth in textual analysis, nor with the contextual historiography. Thirdly, and this is also one of our concerns, we intend to present a new alternative interpretation of the Tractatus in the context of Brazilian scholarship, which does not even recognize the possibility of a Hertzian interpretation of that work. Our interpreters either interpret the Tractatus from the mathematical or logical point of view, or from the bias of the mystical experience of initiation into silence; it does not consider scientific/philosophical influences and therefore it is far removed from Wittgenstein's own statement that his work "projected itself from the foundations of logic to the nature of the world." Fourthly, little has been done to locate the true place of Wittgenstein in the edifice of contemporary science. If we were to begin by understanding his real influence on the Vienna Circle, as well the approximation of his ideal of significant proposition to the conception of a scientific language free from any trace of metaphysics - typical of the Circle - we might succeed in this endeavor. However, to achieve this the first step would be to understand the foundation of his own conception of science and scientific language; for that, the thought of Hertz would once again come into play. Finally, we see for the first time in the history of philosophy a light at the end of the tunnel, a chance to understand what the notorious object of Wittgenstein is, and how to conceive it within his ontology, and this can only be achieved by understanding the mechanistic atomism of the system of Hertz.

All these question point to the relevance of the Hertzian reading of the Tractatus, from which new light is shed on the central themes of the Tractatus.

\section{References}

BOLTZMANN, L. Escritos populares. Trad. Antônio A. P. Videira. São Leopoldo-RS: Editora Unisinos, 2004.

HERTZ, H. The Principles of Mechanics Presented in a New Form. Pref. W. Von Helmholtz. Trad. D. E. Jones e J. T. Walley. Intr. R. S. Cohen. New York: Dover Publications. 1956.

McGUINNES, B. F. Wittgenstein: A Life - Young Ludwige 1889-1921. Berkeley: University of California Press, 1988.

MONK, Ray. Wittgenstein: o dever do gênio. Tradução Carlos Afonso Malferrari. São Paulo: Cia das Letras, 1995.

WITTGENSTEIN, L. [1914-1916]. Notebooks [NB]. Ed. G. H. von Wright e G. E. M. Anscombe. Oxford: Basil Blackwell, 1969.

WITTGENSTEIN, L. [1922]. Tractatus Logico-Philosophicus [TLP]. B. Russell, F. R. S. - Introdução. Trad., apres. e ensaio introdutório de Luiz Henrique Lopes dos Santos. São Paulo: EDUSP, 1995. 


\section{Sobre o autor}

\section{Eduardo Simões Silva}

Possui graduação em Filosofia pela Universidade Estadual de Montes Claros (2001), mestrado (2008) e doutorado (2012) em Filosofia pela Universidade Federal de São Carlos (UFSCar). Tem experiência na área de Filosofia atuando com temas ligados à Lógica, Filosofia da Linguagem, Filosofia da Ciência, Ética, H. Hertz e L. Wittgenstein. Atuou em atividades administrativas e de representação como coordenador de pós-graduação e coordenador de pesquisa. É autor dos livros "Wittgenstein e o Problema da Verdade" (2008), "Lógica Formal e Ética" (2009), "Hertz, Wittgenstein e a Representação do Mundo" (2012), além de um livro na área de Metodologia Científica intitulado "Manual para Normalização de Projetos de Pesquisa, Monografia e Trabalhos Científicos" (2014). Atualmente é professor adjunto (DE) do curso de Filosofia da Universidade Federal do Tocantins, bem como, Avaliador do Sistema Nacional de Avaliação da Educação Superior (INEP - MEC). É membro da Sociedade Brasileira de Filosofia Analítica.

Recebido em 09/12/2018

Aprovado em 12/07/2019

\section{Como referenciar esse artigo}

SILVA, Eduardo Simões. A brief introduction to a Hertzian reading of Wittgenstein's Tractatus. Argumentos: Revista de Filosofia. Fortaleza, ano 11, n. 22, p. 32-38, jul.-dez. 2019. 